\title{
A Role for Soluble IL-6 Receptor in Osteoarthritis
}

\author{
Graham Akeson ${ }^{1}$ and Charles J. Malemud ${ }^{1,2, *}$ \\ 1 Department of Medicine, Division of Rheumatic Diseases, Case Western Reserve University School of \\ Medicine and University Hospitals Cleveland Medical Center, Cleveland, OH 44106, USA; \\ graham.akeson@case.edu \\ 2 Department of Medicine, University Hospitals Cleveland Medical Center, Foley Medical Building, \\ 2061 Cornell Road, Room 207, Cleveland, OH 44106-5076, USA \\ * Correspondence: cjm4@cwru.edu; Tel.: +1-(216)-844-7846 or +1-(216)-536-1945; Fax: +1-(216)-844-2288
}

Received: 30 May 2017; Accepted: 25 July 2017; Published: 2 August 2017

\begin{abstract}
Interleukin-6 (IL-6) is one of several pro-inflammatory cytokines present at elevated levels in the synovial fluid of individuals with confirmed clinical diagnosis of rheumatoid arthritis (RA) and osteoarthritis (OA). The mechanism of action of IL-6 was shown to involve its capacity to interact with a membrane-bound IL-6 receptor (mIL-6R $\alpha$ ), also known as the "classical" IL-6 pathway, or through its interaction with a soluble IL-6 receptor (sIL-6R) termed the "trans-signaling" pathway. Activation of downstream signaling is transduced via these IL-6 receptors and principally involves the Janus Kinase/Signal Transduction and Activators of Transcription (JAK/STAT) signaling pathway that is further regulated by glycoprotein-130 (gp130) interacting with the IL-6/mIL-6R complex. Phosphorylation of STAT proteins via JAK activation facilitates STAT proteins to act as transcription factors in inflammation. However, the biological function(s) of the sIL-6R in human chondrocytes requires further elucidation, although we previously showed that exogenous sIL-6R significantly suppressed the synthesis of neutrophil gelatinase-associated lipocalin (NGAL) in the immortalized line of human chondrocytes, C28/I2. NGAL was shown to regulate the activity of matrix metalloproteinase-9 (MMP-9), whose activity is crucial in OA for the destruction of articular cartilage. The "shedding" of sIL-6R from the plasma membrane is carried out by a family of enzymes known as A Distintegrin and Metalloproteinase (ADAM), which are also elevated in OA. In this paper, we have systematically reviewed the role played by IL-6 in OA. We have proposed that sIL-6R may be an important target for future drug development in OA by ameliorating cartilage extracellular protein degradation.
\end{abstract}

Keywords: a disintegrin and metalloproteinase; cytokines; inflammation; interleukin-6; interleukin-6 receptor; osteoarthritis; signal transduction

\section{Introduction}

At the pathophysiological level, human osteoarthritis (OA) can best be described as a systemic disturbance [1,2] primarily involving large and small diarthrodial synovial joints [3]. Although the aetiopathogenesis of OA remains debatable, an examination of simple radiographs suggested that subtle changes in the anatomical structure of synovial joints, which can evolve during the ageing process, may be a contributing factor in the development of human generalized OA [4]. In addition, several components of cartilage and bone metabolism converge in OA which include genetic, mechanical, and microenvironmental stresses that are known to influence the progression of primary generalized and synovial joint-specific OA [5].

Just as important as genetic and mechanical stressors are to the development of OA was the recognition that a type of "non-classical" inflammation was also a significant contributing factor in the progression of OA [6-9]. Thus, accumulating evidence now appears to show that 
a chronic form of synovitis is a critical component that drives the progression of $\mathrm{OA}$ [3,10-12]. Furthermore, the cellular infiltrates commonly associated with immune-mediated synovial tissue inflammation as seen in rheumatoid arthritis (RA), is evidenced in OA by the presence of activated T-lymphocytes [13-15]. There are also other cell-mediated inflammation biomarkers found in OA, including elevated levels of nitric oxide, prostaglandin $\mathrm{E}_{2}$, and neuropeptides [3]. Taken together with this and other evidence [3,5,7-9] these findings provide putative cellular and molecular mechanisms, as well as the pathophysiological underpinning for considering a role for immune cell and non-immune cell-mediated inflammation in OA together with the new data pointing to potential novel therapies for OA that could be developed based on those findings.

The inflammatory component of OA, as evidenced by chronic synovitis, is associated with a modulation of the chondrogenic phenotype. These changes include the upregulation of pro-inflammatory cytokine gene expression [16]; the upregulation of matrix metalloproteinase (MMP) gene expression $[9,17,18]$ combined with a skewing of the ratio of the level of tissue inhibitor of metalloproteinases (TIMPs) to MMPs towards MMPs has also been considered as relevant; elevated expression of a disintegrin and metalloproteinases with thrombospondin motif (ADAMTS) genes [19]; and a disintegrin and metalloproteinase (ADAM) genes [20], the production of alarmins and Toll-like receptors [21], and an increased frequency of chondrocyte apoptosis [22]. These changes are likely to be arise from aberrations in signal transduction involving the mitogen-activated protein kinase (MAPK) and Janus Kinase/Signal Transduction and Activators of Transcription (JAK/STAT) pathways, negative regulators of JAK/STAT [23-26], and by those cytokines that activate the nuclear factor- $\mathrm{KB}$ (NF-kB) pathway [27-29].

Interleukin-6 (IL-6), in addition to other cytokines belonging to the IL-6 family of proteins, which include oncostatin M [30] and adiponectin (a member of the adipokine family) [9,31], are among the most prominently elevated cytokines involved in the inflammatory response in OA. In that regard, it will be imperative that we further our understanding of the molecular mechanisms underlying the interaction between IL-6-type cytokines with the membrane form of the IL-6 receptor known as mIL-6R $\alpha / g p 130$ and the soluble IL-6R form (sIL-6), as well as other respective membrane-bound receptors.

Of note, Livshits et al. [32] showed that an increase in the levels of circulating IL-6, as well as higher body mass index, had a predictive value in the development of confirmed radiographic knee OA. Furthermore, Blumenfeld et al. [33] studied thousands of female patients in the United Kingdom and found that single nucleotide polymorphisms (SNPs) in the IL-6 genomic region were associated with radiographic evidence of hand OA and an "osteoporosis-related phenotype" of the hand, suggesting that specific DNA motifs in the IL-6 gene represented by these IL-6 SNPs contributed to the development of hand OA and osteoporotic-related changes in the hand.

With this in mind, we have briefly reviewed the current state of knowledge of how OA alters articular cartilage homeostasis and, in that regard, have explored the molecular mechanism by which the mIL-6R and/or sIL-6R can regulate articular chondrocyte gene expression in OA. Moreover, we propose a strategy by which sIL6R could be manipulated to ameliorate the progression of cartilage degradation in OA.

\section{Cartilage Alterations in Osteoarthritis (OA)}

The major changes occurring in OA of large diarthrodial synovial joints, such as hip, knee, and shoulder, involve significant alterations in articular cartilage and subchondral bone homeostasis, both of which are evidenced by radiographic or histologic evidence of osteophyte formation, chondrocyte senescence, and the increased frequency of apoptotic chondrocytes in articular cartilage as OA progresses $[22,34,35]$. However, the earliest measured changes in articular cartilage in OA also suggested a burst of hypermetabolic activity resulting from chondrocyte proliferation and an elevated production of proteoglycans and collagens [36]. At this stage of OA, subchondral bone cell homeostasis may also be perturbed [37], which is likely to be a precursor of, and eventually leads to, boney sclerosis. 
However, at its core, OA is characterized by an imbalance between anabolic and catabolic events leaning towards catabolism [38-40]. Thus, the significantly elevated levels of MMP, ADAMs, and ADAMTS activity in OA synovial fluid, which is caused by stimulation from pro-inflammatory cytokines, including TNF- $\alpha$, IL-6, OSM, IL-17, and IL-1 $\beta$, as well as an increased production of reactive oxygen species, lead to cartilage extracellular matrix protein (ECM) degradation and the loss of sulfated proteoglycans, collagens $[10,41]$, and accessory matrix proteins, such as fragmented fibronectin, from the tissue. In particular, OSM, in concert with TNF- $\alpha$ and IL-1 $\beta$, have been implicated in the inflammatory process associated with OA wherein OSM mediated the degradation of aggrecan and hyaluronan, and where aggrecan degradation was associated with an increase in the low molecular weight G3 product of aggrecan [42]. Furthermore, Ni et al. [43] suggested that OSM may be involved in altering the metabolism of bone associated with OA progression. In addition, Greene and Loesser [44] showed that the chondrocyte in response to OSM and IL-1 $\beta$, as well as growth factors such as IGF-1, may be responsible for initiating "cross-talk" between PI3K-Akt, MAP kinase, and the JAK-STAT pathways, which could provide the mechanism in OA for the differential responsiveness between anabolic and catabolic pathways in response to these factors.

This, in turn, not only results in a potent inflammatory response brought about by the egress of ECM protein fragments from cartilage into the synovial fluid, but also significantly compromises articular cartilage integrity, and also alters synovial joint biomechanical properties [45,46].

\section{3. "Classical” IL-6 Signaling Versus IL-6 Trans-Signaling}

Interleukin-6 (IL-6) is one of several cytokine regulators of inflammation. At present, there are two principal mechanisms by which IL-6 is known to interact with its target cells. The "classical" pathway of IL-6 signaling involves membrane-bound IL-6 receptors (mIL-6R/mIL-6R $\alpha$ ) which associate with membrane-bound gp130 [47]. Gp130, when engaged by IL-6 bound to IL-6R, serves as a locus for a tyrosine kinase cascade, resulting in the activation of JAK/STAT and Src-family kinase signaling pathways [47-51], as well as ERK and PI3K/Akt/mTOR signaling [22,44,52]. However, only a limited number of cell types express membrane-bound mIL-6R, including hepatocytes, neutrophils, monocytes, macrophages, as well as naive and memory T-cells $[53,54]$. IL-6R is also known to interact with ciliary neurotrophic factor [55].

IL-6R does not contain a signal-transduction domain. Gp130 serves as the signal transducer for IL-6R [47-51], and gp130 is a target for small-molecule inhibition of inflammatory pathways [56]. Circulating gp130 can bind to IL-6/sIL-6R complex, inactivating the complex, as well as sequestering the signaling molecules. This mechanism creates an IL-6 buffer. Thus, for classical or trans-signaling to occur, the concentration of IL-6 must be high enough so that the signal is not diluted by functional cytokine loss due to circulating gp130. This observation led to a therapeutic development with soluble gp130 employed as an IL-6 inhibitor [57].

Cells expressing membrane-bound IL-6R are the source of soluble IL-6R (sIL-6R) [58], and this soluble receptor is the mediator of the IL-6-trans signaling pathway. Approximately $80 \%$ of sIL-6R is produced by proteolytic cleavage of the membrane-bound IL-6R via ADAM 17 [59], and direct synthesis of the soluble receptor contributes to $20 \%$ of the circulating level of sIL-6R [59]. Once mIL-6R is released, IL-6 can bind to sIL-6R. This receptor-ligand pair interacts with membrane-bound gp130 which is expressed by a majority of cell types [60]. In that regard, once engaged, the gp130/sIL-6R/IL-6 complex induces protein kinase activity within the cell and activation of the JAK/STAT pathway [24], among other protein kinase pathways [61].

IL-6 does not require an IL-6 specific membrane-bound receptor to induce a response. This means that gp130 serves as the signal-transducing domain for both the classical- and trans-signaling pathways [62]. However, a novel mechanism of IL-6 signaling (termed "cluster signaling") has been described for the development of $\mathrm{T}_{\mathrm{h}} 17$ cells in this pathway, membrane-bound IL-6/IL-6R/gp130 complex that is found on dendritic cells binds to and activates membrane-bound Gp130 on T-cells, promoting FoxP3 activation, which induces $\mathrm{T}_{\mathrm{h}} 17$ differentiation [63]. Thus, the proximal 
downstream response to IL-6 signaling does not seem to differ between cells based solely on the presence or absence of mIL-6R [64]. Accumulating evidence indicates that differences in phenotypic expression occur in response to "classical" IL-6 stimulation versus IL-6 trans-stimulation. Stimulation from the "classical" IL-6 pathway appears to primarily produce an anti-inflammatory effect [65], whereas trans-IL-6-stimulation predominantly results in a pro-inflammatory effect [66]. Of note, the homogenous nature of these signal transduction pathways can produce opposite phenotypes because the genomic targets of IL-6 signaling can vary based on cell type [67].

\section{Metzincin Proteases Contribute to the Formation sIL-6R}

IL-6 plays a pivotal role in many immune-cell-mediated responses in various disease states, including cancer [68] and arthritis [25]. As previously stated, the "classical" pathway of IL-6-mediated signal transduction involves membrane-bound IL-6R (mIL-6R; CD126). Thus, following the interaction of IL-6 with mIL-6R, two gp130 co-receptor molecules (CD130) are recruited to the IL-6/mIL-6R complex. In that manner, the recruitment of gp130 to mIL-6R provides the molecular mechanism for activating JAK/STAT signal transduction pathway [24]. Thus, STAT protein activation can provide the dominant signaling mechanism for increasing the level of pro-inflammatory cytokines in various arthritic disorders [18,24,25]. We have previously discussed the types of cytokines and growth factors that activate JAK/STAT signaling and the canonical IL-6 pathway, as well as the negative regulators of JAK/STAT signaling $[24,26]$ and the numerous downstream events which are coupled to STAT protein activation [24].

However, proteolytic cleavage of the mIL-6R protein is mediated by a class of enzymes termed metzincin proteases [69] which yields a soluble form of the IL-6R (sIL-6R). In addition, but to a lesser extent, the synthesis of mIL-6R can arise from an alternatively-spliced mIL-6R mRNA which can, therefore, result in the synthesis of a soluble form of IL-6R (sIL-6R) that can also interact with IL-6 [68,70]. Importantly, Rose-John [70] defined sIL-6R as the critical component in IL-6-mediated signaling wherein the degree of IL-6-trans-signaling versus "classical" mIL-6R signaling regulated the apparent dichotomy between the pro-inflammatory and anti-inflammatory properties of IL-6.

As previously indicated, the generation of sIL-6R is carried out by a molecular mechanism termed, "ectodomain shedding" or shedding [71-73]. Thus, shedding is facilitated by the ADAM class of metzincin proteases (Figure 1) [74]. As reviewed by Giebeler and Zigrino [74], the term "disintegrin" was originally employed to characterize a cysteine-rich RDG-domain in snake venom which was capable of binding to integrins, as well as by the capacity of snake venom to inhibit platelet aggregation in persons bitten by venomous snakes. In that respect, ADAMs are similar in structure to snake venom metalloproteinases (SVMP) (Figure 1) in their capacity to adhere to integrins, although the integrin binding sequence of the ADAMs differs from that of the SVMPs, the former containing mostly aspartic-acid sequences, with the exception of ADAM15 [73]. In the current context, deregulated shedding of membrane proteins by ADAM proteases has often been found in association with autoimmune disorders, cardiovascular diseases, neurodegeneration, cancer, infections, and a general state of inflammation [72].

In the case of mIL-6R, the enzymatic cleavage of mIL-6R occurs most notably by the action of either or both ADAM10 and ADAM17 [75,76], although the assigned level of importance of ADAM10 in cancer and neurodegenerative diseases, such as Alzheimer's disease [77], appears to make ADAM17 more crucial to its role in inflammation associated with autoimmunity [72]. In this regard, Schumacher et al. [78] showed that, after induction, the endogenous form of IL-6R from both human and mouse sources was shed due to the action of ADAM17, whereas constitutive shedding of IL-6R was, to a greater extent, mediated by ADAM10. In fact, it now can be stated with some certainty that ADAM10 mediates the constitutive release of sIL-6R from liver and hematopoietic cells which has been characterized as a slow process [78], whereas ADAM17 is more clearly involved with the regulation of sIL-6R release from neutrophils during both acute and chronic inflammation [75]. 


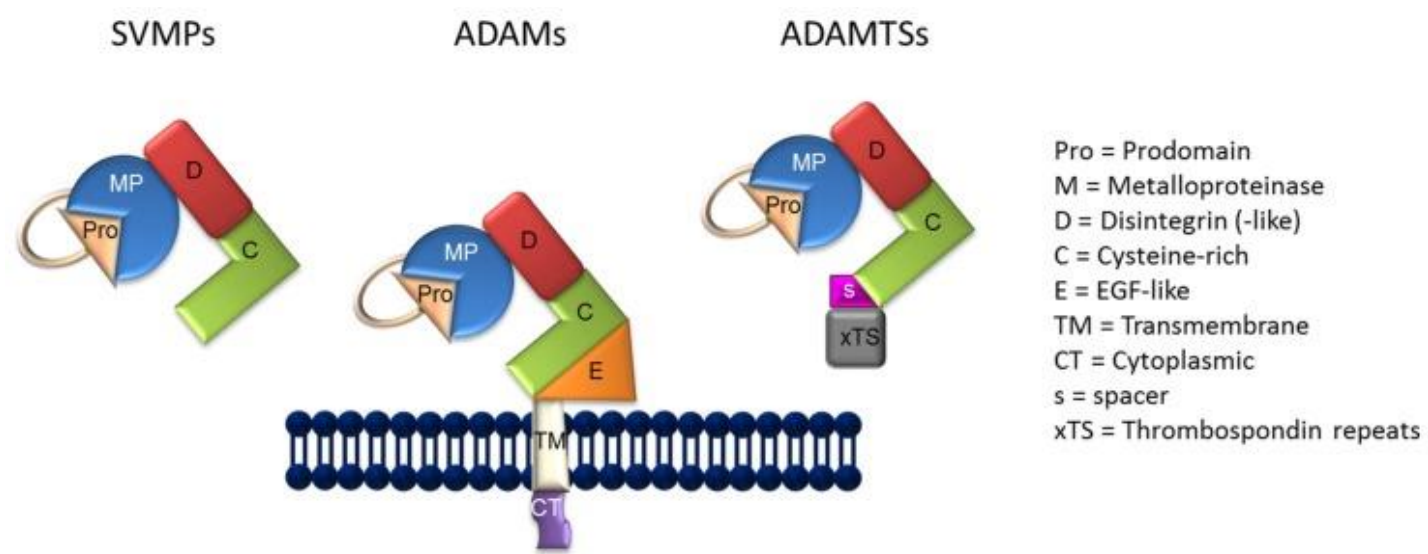

Figure 1. The general structure of snake venom metalloproteinases (SVMPs), A Distintegrin and Metalloproteinase (ADAMs), and ADAMTSs.

ADAM17 is a component of the plasma membrane [79,80], and also called tumor necrosis factor- $\alpha$ converting enzyme (TACE). TACE, in addition to being capable of cleaving mIL-6R to produce sIL-6R, can also cleave ligands for ErbB, including transforming growth factor- $\alpha$ and amphiregulin. TACE is also implicated in the cleavage of some adhesion proteins, such as L-selectin and ICAM-1 [81,82]. Also noteworthy was the finding that naturally-occurring isoforms of soluble gp130 were potentially endogenous inhibitors of sIL-6R-mediated signaling, in which case soluble gp130 would be an active component in the absence of "classical" IL-6 signaling [83]. In contrast to ADAM17, ADAM10 plays a significant role in the shedding of other substrates, including Notch, E-cadherin, epidermal growth factor, ErbB2, and inflammatory cytokines [84]. In addition, the shedding of Notch and CD23 by ADAM10 was also reported to be critical for lymphocyte development [85]. Thus, it was not unexpected that hydroxamate inhibitors of ADAM10 and ADAM17, exemplified by G1254023X and GW280264X, were evaluated as preferential inhibitors of cellular constitutive "ectodomain shedding" but without possessing the activity required to alter the capacity of ADAM10 and ADAM17 to induce "shedding" in response to phorbol esters, such as phorbol myristate acetate [86]. Importantly, in cell-based cleavage analyses, G1254023X blocked the constitutive release of mIL-6R, as well as the release of chemokines, CX3CL1/fractalkine and chemokine C-X-C ligand-16. These latter results were consistent with the reported role of ADAM10 in the release of soluble chemokine peptides [86].

A search of the PubMed database which was employed, in part, to select papers to be included in this review revealed several additional results of studies which investigated these hydroxamate compounds for their capacity to inhibit various ADAM-associated activities using cell-based assays [87-90]. Not unexpectedly, selective small molecular inhibitors of ADAM17/TACE have also been studied for their potential use as a future therapy for rheumatoid arthritis [91].

\section{A Role for the ADAMs in OA?}

Slightly more than a decade ago Campard et al. [92] showed that sIL-6R produced by shedding from peripheral blood-derived $\mathrm{CD} 133^{+}$cells purified to yield hematopoietic stem cells was abrogated by the ADAMs inhibitor, tumor necrosis factor- $\alpha$ protease inhibitor- 1 . This finding suggested that mIL-6R was not only the substrate for the shedding event but, moreover, that sIL-6R could also play a role in both the autocrine and paracrine loops which drives human stem cell development. In fact, in subsequent studies, ADAM17 was identified as the ADAM that mediated the shedding of mIL-6R [83], which produced sIL-6R that could be further processed by the activity of $\alpha$-secretase into smaller peptides.

The shedding of mIL-6R in response to ADAM proteases also appears to be, in part, under genetic regulation since a single nucleotide polymorphism, rs2228145 in the $I L-6 R$ gene (i.e., the IL-6R Asp358Ala variant), conferred an increased susceptibility of mIL-6R to ADAM10- and 
ADAM17-mediated shedding [93]. Importantly, ADAM9, ADAM10, and ADAM12 levels were found to be at increased levels in human OA along with other MMPs and the ADAMTS [20]. Furthermore, the finding of an elevated level of activity of ADAM17 in OA cartilage in which the rare double-secreted frizzled-related protein was expressed [94,95] suggested that the origin of sIL-6R in OA cartilage was likely due to the "sheddase" activity of ADAM17. Importantly, Yan et al. [96] recently identified the natural protease required for the shedding of murine mIL-6R $\alpha$ using hypomorphic ADAM10 or conditional ADAM17 knockout mice. In that paper, Yan et al. [96] showed that infection in these mice with Listeria monocytogenes caused the shedding of IL-6R $\alpha$ by ADAM17 which was rapidly induced in leukocytes. However, $\mathrm{CD}^{+}$-Cre-driven ADAM10 deletion in T-cells obtained from these mice did not alter mIL-6R $\alpha$ shedding. This finding substantiated the role that ADAM17 played in producing sIL-6R following a challenge with an inflammatory stressor. Furthermore, a mechanism involving ADAM17 may also contribute to the increase in the biological availability and activity of sIL-6R in various types of arthritis [97] (also, see below).

We have previously shown that human chondrocytes enzymatically dissociated from OA knee cartilage synthesized neutrophil gelatinase-associated lipocalin (NGAL) in response to exogenous IL-1 $\beta$ [98]. Importantly, we have also previously shown that NGAL exists in a complex with MMP-9 (92 kDa gelatinase; gelatinase B) in synovial fluids sampled from OA patients undergoing joint replacement surgery [99]. Moreover, we showed that the MMP-9/NGAL complex was responsible for maintaining MMP-9 in its active state because when the MMP-9/NGAL complex was disrupted, MMP-9 activity was lost. We also found that exogenous sIL-6R, but not exogenous recombinant human IL-6 (rhIL-6), was a potent inhibitor of NGAL production in the immortalized human chondrocyte line, C28/I2 [100]. Furthermore, we reported that the combination of rhIL-6 and sIL-6R failed to suppress NGAL production, nor did exogenous tocilizumab (TCZ), a monoclonal antibody that blocks IL-6 signaling [101]. However, the combination of rhIL-6 and TCZ also inhibited NGAL production by C28/I2 human chondrocytes. Taken together with other data [102], we suggested that endogenous sIL-6R could potentially be manipulated so that it would behave as an inhibitor of NGAL production. This advance could limit the potential deleterious effects of MMP-9 on articular cartilage degradation in RA and OA.

\section{Conclusions and Future Perspective}

Meszaros and Malemud [5] reviewed the state of drug development for OA, which emphasized the fact that an OA-specific drug had yet to be developed. However, because the ADAMTS were also shown to be critical enzymes in OA cartilage for producing fragments of the sulfated proteoglycan, aggrecan, ADAMTS-4 and ADAMTS-5, in particular, have been targeted for potential future therapy of OA [103]. In that regard, IL-6 was shown to upregulate the expression of ADAMTS-4 [104]. Furthermore, the expression of the ADAMTS-4 gene was upregulated in vitro by the combination of IL-6 and sIL-6R-treated RA-fibroblast-like synoviocytes, whereas ADAMTS-5 was decreased. Of note, both ADAMTS- 4 and ADAMTS- 5 gene expression were dependent on IL-6/sIL-6R-mediated trans-activation of JAK/STAT. Therefore, in an important first step going forward it will be vital to critically and systematically evaluate the extent to which sIL-6R differentially regulates the activation of JAK/STAT signaling, as well as ADAMS/ADAMTS production, in human OA chondrocytes when those chondrocytes are compared to chondrocytes isolated from age-matched non-arthritis human cartilage. However, it will also be critical to consider that any pharmacologic approach to inhibiting ADAM proteases may produce important adverse side-effects. For example, because ADAM proteases also play a crucial role in developmental and regenerative processes [105], it will be incumbent to more accurately define both the temporal and spatial involvement of ADAM proteases in OA.

Acknowledgments: The experimental results cited in references [98-100,102] were supported by grants from Genentech/Roche Group (South San Francisco, CA), by the CWRU Visual Sciences Research Center Core Grant, P30-EY-11373 and, by grants R01 AR-48782 and AT-002258 from the National Institutes of Health.

Conflicts of Interest: The authors declare no conflict of interest. 


\section{References}

1. Denko, C.W.; Malemud, C.J. Metabolic disturbances and synovial joint responses in osteoarthritis. Front. Biosci. 1999, 4, d686-d693. [CrossRef] [PubMed]

2. Cicuttini, F.M.; Wluka, A.E. Osteoarthritis: Is OA a mechanical or systemic disease? Nat. Rev. Rheumatol. 2014, 10, 515-516. [PubMed]

3. Sellam, J.; Berenbaum, F. The role of synovitis in pathophysiology and clinical symptoms of osteoarthritis. Nat. Rev. Rheumatol. 2010, 6, 625-635. [CrossRef] [PubMed]

4. Hügle, T.; Geurts, J.; Nüesch, G.; Müller-Gerbi, M.; Valderrabono, V. Aging and osteoarthritis: An inevitable encounter? J. Aging Res. 2012, 2012, 950192. [PubMed]

5. Meszaros, E.; Malemud, C.J. Prospects for treating osteoarthritis: Enzyme-protein interactions regulating matrix metalloproteinase activity. Ther. Adv. Chronic Dis. 2012, 3, 219-229. [CrossRef] [PubMed]

6. Pelletier, J.-P.; Martel-Pelletier, J.; Abramson, S.B. Osteoarthritis, an inflammatory disease: Potential implications for the selection of new therapeutic targets. Arthritis Rheum. 2001, 44, 1237-1247. [PubMed]

7. Malemud, C.J.; Islam, N.; Haqqi, T.M. Pathophysiological mechanisms in osteoarthritis lead to novel therapeutic strategies. Cells Tissues Organs 2003, 174, 34-48. [PubMed]

8. Goldring, M.B.; Otero, M. Inflammation in osteoarthritis. Curr. Opin. Rheumatol. 2011, 23, 471-478. [CrossRef] [PubMed]

9. Malemud, C.J. The biological basis of osteoarthritis: State of the evidence. Curr. Opin. Rheumatol. 2015, 27, 289-294. [CrossRef] [PubMed]

10. Malemud, C.J.; Schulte, M.E. Is there a final common pathway for arthritis? Future Rheumatol. 2008, 3, 253-268.

11. Scanzello, C.R.; Goldring, S.R. The role of synovitis in osteoarthritis pathogenesis. Bone 2012, 51, $249-257$. [CrossRef] [PubMed]

12. Berenbaum, F. Osteoarthritis as an inflammatory disease (osteoarthritis is not osteoarthrosis!). Osteoarthr. Cartil. 2013, 21, 16-21. [CrossRef] [PubMed]

13. Sakkas, L.I.; Platsoucas, P.D. The role of T cells in the pathogenesis of osteoarthritis. Arthritis Rheum. 2007, 56, 409-424. [CrossRef] [PubMed]

14. De Lange-Brokkar, B.J.; Ioan-Facsinay, A.; van Osch, G.J.; Zuurmond, A.M.; Schoones, J.; Toes, R.E.; Huizinga, T.W.; Kloppenberg, M. Synovial inflammation, immune cells, and their cytokines in osteoarthritis: A review. Osteoarthr. Cartil. 2012, 20, 1484-1499. [CrossRef] [PubMed]

15. Haseeb, A.; Haqqi, T.M. Immunopathogenesis of osteoarthritis. Clin. Immunol. 2013, 146, 185-196. [CrossRef] [PubMed]

16. Kapoor, M.; Martel-Pelletier, J.; Lajeunesse, D.; Pelletier, J.-P.; Fahmi, H. Role of proinflammatory cytokines in the pathophysiology of osteoarthritis. Nat. Rev. Rheumatol. 2011, 7, 33-42. [CrossRef] [PubMed]

17. Gargiulo, S.; Gamba, P.; Poli, G.; Leonarduzzi, G. Metalloproteinases and metalloproteinase inhibitors in age-related diseases. Curr. Pharm. Des. 2014, 20, 2993-3018. [CrossRef] [PubMed]

18. Malemud, C.J. Matrix Metalloproteinases and Tissue Remodeling in Health and Disease Part II. Target Tissues and Therapy; Elsevier: Amsterdam, The Netherlands, 2017; pp. 306-325.

19. Verma, P.; Dakal, K. ADAMTS-4 and ADAMTS-5: Key enzymes in osteoarthritis. J. Cell. Biochem. 2011, 112, 3507-3514. [CrossRef] [PubMed]

20. Yang, C.Y.; Chanalaris, A.; Troeberg, L. ADAMTS and ADAM metalloproteinases in osteoarthritis-Looking beyond the 'usual suspects'. Osteoarthr. Cartil. 2017, 25, 1000-1009. [CrossRef] [PubMed]

21. Huard, X.; Goldring, M.B.; Berenbaum, F. Homeostatic mechanisms in articular cartilage and role of inflammation in osteoarthritis. Curr. Rheumatol. Rep. 2013, 15, 375. [CrossRef] [PubMed]

22. Wylie, M.A.; Malemud, C.J. Perspective: Deregulation of apoptosis in arthritis by altered signal transduction. Int. J. Clin. Rheumatol. 2013, 8, 483-490. [CrossRef]

23. Malemud, C.J. Osteoarthritis, Inflammation and Degradation: A Continuum; Volume, 70: Biomedical and Health Research; IOS Press: Amsterdam, The Netherlands, 2007; pp. 99-117.

24. Malemud, C.J.; Pearlman, E. Targeting JAK/STAT signaling pathway in inflammatory diseases. Curr. Signal Transduct. Ther. 2009, 4, 201-221. [CrossRef]

25. Malemud, C.J. Drug Discovery; InTech Publishing: Rijeka, Croatia, 2013; pp. 373-411. 
26. Malemud, C.J. Negative regulators of JAK/STAT signaling in rheumatoid arthritis and osteoarthritis. Int. J. Mol. Sci. 2017, 18, 484. [CrossRef] [PubMed]

27. Melas, I.N.; Chairakaki, A.D.; Chatzopoulou, E.I.; Messinis, D.E.; Katopodi, T.; Pilaka, V.; Samara, S.; Mitsos, A.; Dailana, Z.; Kollia, P.; et al. Modeling of signaling pathways in chondrocytes based on phosphoproteomics and cytokine release data. Osteoarthr. Cartil. 2014, 22, 509-518. [CrossRef] [PubMed]

28. Wu, L.; Huang, X.; Li, L.; Huang, H.; Xu, R.; Luyten, W. Insights on biology and pathology of HIF-1 $\alpha /-2 \alpha$, TGF $\beta$ /BMP, Wnt/ $\beta$-catenin and NF-kB pathways in osteoarthritis. Curr. Pharm. Des. 2012, 18, 3293-3312. [CrossRef] [PubMed]

29. Rigoglou, S.; Papavassilou, A.G. The NF-кB signaling pathway in osteoarthritis. Int. J. Biochem. Cell. Biol. 2013, 45, 2580-2584. [CrossRef] [PubMed]

30. Tsuchida, A.I.; Beekhuizen, M.T.; Ct Hart, M.C.; Radstake, T.R.; Dhert, W.A.; Saris, W.B.; van Osch, G.J.; Creemers, L.B. Cytokine profiles in the joint depend on pathology, but are different between synovial fluid, cartilage tissue and cultured chondrocytes. Arthritis Res. Ther. 2014, 16, 441. [CrossRef] [PubMed]

31. DeBoer, T.N.; van Spil, W.E.; Huisman, A.M.; Polak, A.A.; Bijlsma, J.W.; Lafeber, F.P.; Mastbergen, F.C. Serum adipokines in osteoarthritis: Comparison with controls and relationship with local parameters of synovial inflammation and cartilage damage. Osteoarthr. Cartil. 2012, 20, 846-853. [CrossRef] [PubMed]

32. Livshits, G.; Zhai, G.; Hart, D.J.; Kato, B.S.; Wang, H.; Williams, F.M.; Spector, T.D. Interleukin-6 is a significant predictor of radiographic knee osteoarthritis: The Chingford study. Arthritis Rheumatol. 2009, 60, 2037-2045. [CrossRef] [PubMed]

33. Blumenfeld, O.; Williams, F.M.; Valdes, A.; Hart, D.J.; Malkin, I.; Spector, T.D.; Livshits, G. Association of interleukin-6 polymorphisms with hand osteoarthritis and hand osteoporosis. Cytokine 2014, 69, 94-101. [CrossRef] [PubMed]

34. Iannone, F.; Lapadula, G. The pathophysiology of osteoarthritis. Aging Clin. Exp. Res. 2003, 15, 364-372. [CrossRef] [PubMed]

35. Goldring, M.; Goldring, S. Osteoarthritis. J. Cell. Physiol. 2007, 213, 626-634. [CrossRef] [PubMed]

36. Sandell, L.; Aigner, T. Articular cartilage and changes in arthritis. An introduction: Cell biology of osteoarthritis. Arthritis Res. 2001, 3, 107-113. [CrossRef] [PubMed]

37. Hulejová, H.; Baresová, V.; Klèzl, Z.; Polanská, M.; Adam, M.; Senolt, L. Increased level of cytokines and matrix metalloproteinases in osteoarthritic subchondral bone. Cytokine 2007, 38, 151-156. [CrossRef] [PubMed]

38. Hollander, A.P.; Pidoux, I.; Reiner, A.; Rorabeck, C.; Bourne, R.; Poole, A.R. Damage to type II collagen in aging and osteoarthritis starts at the articular surface, originates around chondrocytes, and extends into the cartilage with progressive degeneration. J. Clin. Investig. 1995, 96, 2859-2869. [CrossRef] [PubMed]

39. Burrage, P.S.; Mix, K.S.; Brinckerhoff, C.E. Matrix metalloproteinases: Role in arthritis. Front. Biosci. 2006, 11, 529-543. [CrossRef] [PubMed]

40. Burrage, P.S.; Brinckerhoff, C.E. Molecular targets in osteoarthritis: Metalloproteinases and their inhibitors. Curr. Drug Targets 2007, 8, 293-303. [CrossRef] [PubMed]

41. Struglics, A.; Larsson, S.; Pratta, M.A.; Kumar, S.; Lark, M.W.; Lohmander, L.S. Human osteoarthritis synovial fluid and joint cartilage contain both aggrecanase- and matrix metalloproteinase-generated aggrecan fragments. Osteoarthr. Cartil. 2006, 14, 101-113. [CrossRef] [PubMed]

42. Durigova, M.; Roughley, P.J.; Mort, J.S. Mechanism of proteoglycan aggregate degradation in cartilage stimulated with oncostatin M. Osteoarthr. Cartil. 2008, 16, 98-104. [CrossRef] [PubMed]

43. Ni, J.; Yuan, X.M.; Yao, Q.; Peng, L.B. OSM is overexpressed in knee osteoarthritis and Notch signaling is involved in the effects of OSM on MC3T3-E1 cell proliferation and differentiation. Int. J. Mol. Med. 2015, 35, 1755-1760. [CrossRef] [PubMed]

44. Greene, M.A.; Loesser, R.F. Function of the chondrocyte PI-3 kinase-Akt signaling pathway is stimulus dependent. Osteoarthr. Cartil. 2015, 23, 949-956. [CrossRef] [PubMed]

45. Mueller, M.B.; Tuan, R.S. Anabolic/catabolic balance in the pathogenesis of osteoarthritis: Identifying molecular targets. PMR 2011, 3, S3-S11. [CrossRef] [PubMed]

46. Hedbom, E.; Häuselmann, H.J. Molecular aspects of pathogenesis in osteoarthritis: The role of inflammation. Cell. Mol. Life Sci. 2002, 59, 45-53. [CrossRef] [PubMed] 
47. Haan, C.; Is'harc, H.; Hermanns, H.M.; Schmitz-Van de Leur, H.; Kerr, I.M.; Heinrich, P.C.; Grötzinger, J.; Behrmann, I. Mapping of a region within the $\mathrm{N}$ terminus of Jak1 involved in cytokine receptor interaction. J. Biol. Chem. 2001, 276, 37451-37458. [CrossRef] [PubMed]

48. Haan, C.; Hermanns, H.M.; Heinrich, P.C.; Behrmann, I. A single amino acid substitution (Trp666 $\rightarrow$ Ala) in the interbox1/2 region of the interleukin-6 signal transducer gp130 abrogates binding of JAK1, and dominantly impairs signal transduction. Biochem. J. 2000, 349, 261-266. [CrossRef] [PubMed]

49. Haan, C.; Heinrich, P.C.; Behrmann, I. Structural requirements of the interleukin-6 signal transducer gp130 for its interaction with Janus kinase 1: The receptor is crucial for kinase activation. Biochem. J. 2002, 361, 105-111. [CrossRef] [PubMed]

50. Hallek, M.; Neumann, C.; Schaffer, M.; Danhauser-Riedl, S.; von Bubnoff, N.; de Vos, G.; Druker, B.J.; Yasukawa, K.; Griffin, J.D.; Emmerich, B. Signal transduction of interleukin-6 involves tyrosine phosphorylation of multiple cytosolic proteins and activation of Src-family kinases Fyn, Hck, and Lyn in multiple myeloma cell lines. Exp. Hematol. 1997, 25, 1367-1377. [PubMed]

51. Schaeffer, M.; Schneiderbauer, M.; Weidler, S.; Tavares, R.; Warmuth, M.; de Vos, G.; Hallek, M. Signaling through a novel domain of gp130 mediates cell proliferation and activation of Hck and Erk kinases. Mol. Cell. Biol. 2001, 21, 8068-8081. [CrossRef] [PubMed]

52. Malemud, C.J. PI3K/Akt/PTEN/mTOR signaling: A fruitful target for inducing cell death in rheumatoid arthritis? Future Med. Chem. 2015, 7, 1137-1147. [CrossRef] [PubMed]

53. Oberg, H.-H.; Wesch, D.; Grüssel, S.; Rose-John, S.; Kabelitz, D. Differential expression of CD126 and CD130 mediates different STAT-3 phosphorylation in $\mathrm{CD} 4{ }^{+} \mathrm{CD} 25^{-}$and $\mathrm{CD} 25^{\text {high }}$ regulatory T cells. Int. Immunol. 2006, 18, 555-563. [CrossRef] [PubMed]

54. Gauldie, J.; Richards, C.; Harnish, D.; Lansdorp, P.; Baumann, H. Interferon $\beta_{2} /$ B-cell stimulatory factor type 2 shares identity with monocyte-derived hepatocyte-stimulating factor and regulates the major acute phase protein response in liver cells. Proc. Natl. Acad. Sci. USA 1987, 84, 7251-7255. [CrossRef]

55. Schuster, B.; Kovaleva, M.; Sun, Y.; Regenhard, P.; Matthews, V.; Grötzinger, J.; Rose-John, S.; Kallen, K.J. Signaling of human ciliary neurotrophic factor (CNTF) revisited. The interleukin-6 receptor can serve as an $\alpha$-receptor for CNTF. J. Biol. Chem. 2003, 278, 9528-9535. [CrossRef] [PubMed]

56. Hong, S.-S.; Choi, J.H.; Lee, S.Y.; Park, Y.-H.; Park, K.-Y.; Lee, J.Y.; Kim, J.; Gajulapati, V.; Goo, J.-I.; Singh, S.; et al. A novel small-molecule inhibitor targeting the IL-6 receptor $\beta$ subunit, glycoprotein 130. J. Immunol. 2015, 195, 237-245. [CrossRef] [PubMed]

57. Ahmed, S.; Marotte, H.; Kwan, K.; Ruth, J.H.; Campbell, P.L.; Rabquer, B.J.; Pakozdi, A.; Koch, A.E. Epigallocatechin-3-gallate inhibits IL-6 synthesis and suppresses transsignaling by enhancing soluble gp130 production. Proc. Natl. Acad. Sci. USA 2008, 105, 14692-14697. [CrossRef] [PubMed]

58. Mülberg, J.; Schooltink, H.; Stoyan, T.; Günther, M.G.; Lutz, B.; Mackiewicz, B.A.; Heinrich, P.C.; Rose-John, S. The soluble interleukin-6 receptor is generated by shedding. Eur. J. Immunol. 1993, 23, 473-480. [CrossRef] [PubMed]

59. Lust, J.A.; Donovan, K.A.; Kline, M.P.; Greipp, P.R.; Kyle, R.A.; Maihle, N.J. Isolation of an mRNA encoding a soluble form of the human interleukin-6 receptor. Cytokine 1992, 4, 96-100. [CrossRef]

60. Taga, T.; Hibi, M.; Hirata, Y.; Yamasaki, K.; Yasukawa, K.; Matsuda, T.; Hirano, T.; Kishimoto, T. Interleukin-6 triggers the association of its receptor with a possible signal transducer, gp130. Cell 1989, 58, 573-581. [CrossRef]

61. Aida, Y.; Honda, K.; Tanigawa, S.; Nakayama, G.; Matsumura, H.; Suzuki, N.; Shimizu, O.; Takeichi, O.; Makimura, M.; Maeno, M. IL-6 and soluble IL-6 receptor stimulate the production of MMPs and their inhibitors via JAK-STAT and ERK-MAPK signalling in human chondrocytes. Cell. Biol. Int. 2012, 36, 367-376. [CrossRef] [PubMed]

62. Scheller, J.; Garbers, C.; Rose-John, S. Interleukin-6: From basic biology to selective blockade of pro-inflammatory activities. Semin. Immunol. 2014, 26, 2-12. [CrossRef] [PubMed]

63. Heink, S.; Yogev, N.; Garbers, C.; Herwerth, M.; Aly, L.; Gasperi, C.; Husterer, V.; Croxford, A.L.; Möller-Hackbarth, K.; et al. Trans-presentation of interleukin- 6 by dendritic cells is required for priming pathogenic $\mathrm{T}_{\mathrm{H}} 17$ cells. Nat. Immunol. 2017, 18, 74-85. [CrossRef] [PubMed]

64. Garbers, C.; Aparicio-Siegmund, S.; Rose-John, S. The IL-6/gp130/STAT3 signaling axis: Recent advances towards specific inhibition. Curr. Opin. Immunol. 2015, 34, 75-82. [CrossRef] [PubMed] 
65. Nowell, M.A.; Richards, P.J.; Horiuchi, S.; Yamamoto, N.; Rose-John, S.; Topley, N.; Williams, A.S.; Jones, S.A. Soluble IL-6 receptor governs IL-6 activity in experimental arthritis: Blockade of arthritis severity by soluble glycoprotein 130. J. Immunol. 2003, 171, 3202-3209. [CrossRef] [PubMed]

66. Campbell, I.L.; Erta, M.; Lim, S.L.; Frausto, R.; May, U.; Rose-John, S.; Scheller, J.; Hidalgo, J. Trans-signaling is a dominant mechanism for the pathogenic actions of interleukin-6 in the brain. J. Neurosci. 2014, 34, 2503-2513. [CrossRef] [PubMed]

67. Hirahara, K.; Atsushi, O.; Villarino, A.V.; Bonelli, M.; Sciumè, G.; Laurence, A.; Sun, H.-W.; Brooks, S.R.; Vahedi, G.; Shih, H.-Y.; et al. Asymmetric action of STAT transcription factors drives transcriptional outputs and cytokine specificity. Immunity 2017, 42, 877-889. [CrossRef] [PubMed]

68. Rose-John, S.; Waetzig, G.H.; Scheller, J.; Grötzinger, J.; Seegert, D. The IL-6/sIL-6R complex as a novel target for therapeutic approaches. Expert Opin. Ther. Targets 2007, 11, 613-624. [CrossRef] [PubMed]

69. Klein, T.; Bischoff, R. Active metalloproteases of the A Disintegrin and Metalloprotease (ADAM) family; biological function and structure. J. Proteome Res. 2011, 10, 17-33. [CrossRef] [PubMed]

70. Rose-John, S. The soluble interleukin-6 receptor and related proteins. Best Pract. Res. Clin. Endocrinol. Metab. 2015, 29, 787-797. [CrossRef] [PubMed]

71. Bridges, L.C.; Bowditch, R.D. ADAM-integrin interactions: Potential integrin regulated ectodomain shedding activity. Curr. Pharm. Des. 2005, 11, 837-847. [CrossRef] [PubMed]

72. Saftig, P.; Reiss, K. The "A Disintegrin and Metalloproteases" ADAM10 and ADAM17: Novel drug targets with therapeutic potential? Eur. J. Cell. Biol. 2011, 90, 527-535. [CrossRef] [PubMed]

73. Hartmann, M.; Herrlich, A.; Herrlich, P. Who decides when to cleave an ectodomain? Trends Biochem. Sci. 2013, 38, 111-120. [CrossRef] [PubMed]

74. Giebeler, N.; Zigrino, P. A disintegrin and metalloprotease (ADAM): Historical overview of their functions. Toxins 2016, 8, 122. [CrossRef] [PubMed]

75. Chalaris, A.; Garbers, C.; Rabe, B.; Rose-John, S.; Scheller, J. The soluble interleukin 6 receptor: Generation and role in inflammation and cancer. Eur. J. Cell. Biol. 2011, 90, 484-494. [CrossRef] [PubMed]

76. Rose-John, S. ADAM17, shedding, TACE as therapeutic targets. Pharmacol. Res. 2013, 71, 19-22. [CrossRef] [PubMed]

77. Endres, K.; Fahrenholtz, F. Regulation of $\alpha$-secretase ADAM10 expression and activity. Exp. Brain Res. 2012, 217, 343-352. [CrossRef] [PubMed]

78. Schumacher, N.; Meyer, D.; Mauermann, A.; von der Heyde, J.; Wolf, J.; Schwarz, J.; Knittler, K.; Murphy, G.; Michalek, M.; Garbers, C.; et al. Shedding of endogenous interleukin-6 receptor (IL-6R) is governed by a distintegrin and metalloprotease (ADAM) proteases while a full-length IL-6R isoform localizes to circulating microvesicles. J. Biol. Chem. 2015, 290, 26059-26071. [CrossRef] [PubMed]

79. Klein, T.; Bischoff, R. Physiology and pathophysiology of matrix metalloproteases. Amino Acids 2011, 41, 271-290. [CrossRef] [PubMed]

80. Xu, J.; Mukerjee, S.; Silva-Alves, C.R.; Carvalho-Galvặo, A.; Cruz, J.C.; Bala rini, C.M.; Braga, V.A.; Lazartiques, E.; Franca-Silva, M.S. A disintegrin and metalloprotease 17 in the cardiovascular and central nervous systems. Front. Physiol. 2016, 7, 469. [CrossRef] [PubMed]

81. Scheller, J.; Chalaris, A.; Garbers, C.; Rose-John, S. ADAM17: A molecular switch to control inflammation and tissue regeneration. Trends Immunol. 2011, 32, 880-887. [CrossRef] [PubMed]

82. Lisi, S.; D'Amore, M.; Sisto, M. ADAM17 at the interface between inflammation and autoimmunity. Immunol. Lett. 2014, 162, 159-169. [CrossRef] [PubMed]

83. Chalaris, A.; Gewiese, J.; Paliga, K.; Fleig, L.; Schneede, A.; Krieger, K.; Rose-John, S.; Scheller, J. ADAM17-mediated shedding of the IL-6R induces cleavage of the membrane stub by $\gamma$-secretase. Biochim. Biophys. Acta 2010, 1803, 234-245. [CrossRef] [PubMed]

84. Crawford, H.C.; Dempsey, P.J.; Brown, G.; Adam, L.; Moss, M.L. ADAM10 as a therapeutic target for cancer and inflammation. Curr. Pharm. Des. 2009, 15, 2288-2299. [CrossRef] [PubMed]

85. Gibb, D.R.; Saleem, S.J.; Chaimowitz, N.S.; Mathews, J.; Conrad, D.H. The emergence of ADAM10 as a regulator of lymphocyte development and autoimmunity. Mol. Immunol. 2011, 48, 1319-1327. [CrossRef] [PubMed] 
86. Ludwig, A.; Hundhausen, C.; Lambert, M.H.; Broadway, N.; Andrews, R.C.; Bickett, D.M.; Lessnitzer, M.A.; Becherer, J.D. Metalloprotease inhibitors for the disintegrin and metalloproteases ADAM10 and ADAM17 that differentially block constitutive and phorbol ester-inducible shedding from cell surface molecules. Comb. Chem. High Throughput Screen. 2005, 8, 161-171. [CrossRef] [PubMed]

87. Jangouk, P.; Dahmel, T.; Meyer Zu Hörst, G.; Ludwig, A.; Lehmann, H.C.; Kieseier, B.C. Involvement of ADAM10 in axonal outgrowth and myelination of the peripheral nerve. Glia 2009, 57, 1765-1774. [CrossRef] [PubMed]

88. Durairajan, S.S.; Liu, L.F.; Lu, J.H.; Koo, I.; Maruyama, K.; Chung, S.K.; Huang, J.D.; Li, M. Stimulation of non-amyloidogenic processing of amyloid-ß protein precursor by cryptotanshinone involves activation and translocation of ADAM10 and PKC- $\alpha$. J. Alzheimers Dis. 2011, 25, 245-262. [PubMed]

89. Dreymueller, D.; Martin, C.; Kogel, T.; Pruessmeyer, J.; Hess, F.M.; Horiuchi, K.; Uhlig, S.; Ludwig, A. Lung epithelial ADAM17 regulates the acute inflammatory response to lipopolysaccharide. EMBO Mol. Med. 2012, 4, 412-423. [CrossRef] [PubMed]

90. Maretzky, T.; Swendeman, S.; Mogollon, E.; Weskamp, G.; Sahin, U.; Reiss, K.; Blobel, C.P. Characterization of the catalytic properties of the membrane-anchored metalloprotease ADAM9 in cell-based assays. Biochem. J. 2017, 474, 1467-1479. [CrossRef] [PubMed]

91. Li, N.G.; Shi, Z.H.; Tang, Y.P.; Wei-Li; Lian-Yin; Duan, J.A. Discovery of selective small molecule TACE inhibitors for the treatment of rheumatoid arthritis. Curr. Med. Chem. 2012, 19, 2924-2956. [PubMed]

92. Campard, D.; Vasse, M.; Rose-John, S.; Poyer, F.; Lamacz, M.; Vannier, J.P. Multilevel regulation of IL-6R by IL-6-sIL-6R fusion protein according to the primitiveness of peripheral blood-derived CD133 ${ }^{+}$cells. Stem Cells 2006, 24, 1302-1314. [CrossRef] [PubMed]

93. Garbers, C.; Monhasery, N.; Aparicio-Siegmund, S.; Lokau, J.; Baran, P.; Nowell, M.A.; Jones, S.A.; Rose-John, S.; Scheller, J. The interleukin-6 receptor, Asp358Ala single nucleotide polymorphism rs2228145 confers increased proteolytic conversion rates by ADAM proteases. Biochim. Biophys. Acta 2014, 1842, 1485-1494. [CrossRef] [PubMed]

94. Muoh, O.; Malemud, C.J.; Askari, A.D. Clinical significance and implications of genetic and genomic studies in patients with osteoarthritis. Adv. Genom. Genet. 2014, 4, 193-206.

95. Oldefest, M.; Düsterhöft, S.; Desel, C.; Thysen, S.; Fink, C.; Rabe, B.; Lories, R.; Grötzinger, J.; Lorenzen, I. Secreted Frizzled-related protein 3 (sFRP3)-mediated suppression of interleukin-6 receptor release by A disintegrin and metalloprotease 17 (ADAM17) is abrogated in the osteoarthritis-associated rare double variant of sFRP3. Biochem. J. 2015, 468, 507-518. [CrossRef] [PubMed]

96. Yan, I.; Schwarz, J.; Lücke, K.; Schumacher, N.; Schumacher, V.; Schmidt, S.; Rabe, B.; Saftig, P.; Donners, M.; Rose-John, S.; et al. ADAM17 controls IL-6 signaling by cleavage of the murine IL-6R $\alpha$ from the cell surface of leukocytes during inflammatory responses. J. Leukoc. Biol. 2016, 99, 749-760. [CrossRef] [PubMed]

97. Reithmueller, S.; Somasundaram, P.; Ehlers, J.C.; Hung, C.W.; Flynn, C.M.; Lokau, J.; Agthe, M.; Düsterhöft, S.; Zhu, Y.; Grötzinger, J.; et al. Proteolytic origin of the soluble human IL-6R in vivo and a decisive role of N-glycosylation. PLoS ONE 2017, 15, e2000080. [CrossRef] [PubMed]

98. Gupta, K.; Shukla, M.; Malemud, C.J.; Cowland, J.; Haqqi, T.M. Neutrophil gelatinase-associated lipocalin (NGAL) is produced by IL-1 $\beta$-stimulated human osteoarthritis chondrocytes and protects MMP-9 from degradation. Osteoarthr. Cartil. 2006, 14, S87-S88. [CrossRef]

99. Gupta, K.; Shukla, M.; Cowland, J.B.; Malemud, C.J.; Haqqi, T.M. Neutrophil gelatinase-associated lipocalin (NGAL) is expressed in osteoarthritis and forms a complex with matrix metalloproteinase-9. Arthritis Rheum. 2007, 56, 3326-3335. [CrossRef] [PubMed]

100. Meszaros, E.C.; Dahoud, W.; Mesiano, S.; Malemud, C.J. Blockade of recombinant human IL-6 with tocilizumab suppresses matrix metalloproteinase- 9 production in the C28/I2 immortalized human chondrocyte cell line. Integr. Mol. Med. 2015, 2, 304-310. [CrossRef] [PubMed]

101. Shetty, A.; Hanson, R.; Korsten, P.; Shawagfeh, M.; Arami, S.; Volkov, S.; Vila, O.; Swedla, W.; Shunaigat, A.S.; Smadi, S.; et al. Tocilizumab in the treatment of rheumatoid arthritis and beyond. Drug Des. Dev. Ther. 2014, $8,349-364$.

102. Malemud, C.J.; Meszaros, E.C.; Wylie, M.A.; Dahoud, W.; Skomorovska-Prokvolit, Y.; Mesiano, S. Matrix metalloproteinase-9 production in immortalized human chondrocyte lines. J. Clin. Cell. Immunol. 2016, 7, 422. [CrossRef] [PubMed] 
103. Kelwick, R.; Desanlis, I.; Wheeler, G.N.; Edwards, D.R. The ADAMTS (a distintegrin and metalloproteinase with thrombospondin motif) family. Genome Biol. 2015, 16, 113. [CrossRef] [PubMed]

104. Mimata, Y.; Kamataki, A.; Oikawa, S.; Murakami, K.; Uzuki, M.; Shimamura, T.; Sawai, T. Interleukin-6 upregulates the expression of ADAMTS-4 in fibroblast-like synoviocytes from patients with rheumatoid arthritis. Int. J. Rheumatol. Dis. 2012, 15, 36-44. [CrossRef] [PubMed]

105. Dreymueller, D.; Ludwig, A. Considerations of inhibition approaches for proinflammatory functions of ADAM proteases. Platelets 2017, 28, 354-361. [CrossRef] [PubMed]

(C) 2017 by the authors. Licensee MDPI, Basel, Switzerland. This article is an open access article distributed under the terms and conditions of the Creative Commons Attribution (CC BY) license (http:/ / creativecommons.org/licenses/by/4.0/). 